\title{
Research on Heterogeneity and Employee Stock Ownership Plan of Listed Companies
}

\author{
Boren Tan \\ Sichuan University \\ Chengdu, China
}

\begin{abstract}
This paper takes the Shanghai and Shenzhen Ashare listed companies as samples to study the influence of corporate heterogeneity on the implementation of employee stock ownership plan in listed companies from three aspects: incentive motivation, corporate governance and senior executive welfare. The results show that encouraging employees' enthusiasm and improving corporate governance are the main motivations for listed companies to implement employee stock ownership plan. In particular, private enterprises, high-tech enterprises, larger enterprises, as well enterprises with a small number of independent directors and board of supervisors are more inclined to implement employee ownership. In addition, the listed companies that have experienced previous stock incentive failure are more motivated to implement employee stock ownership.
\end{abstract}

Keywords-employee stock ownership; implementation motivation; senior executive welfare

\section{INTRODUCTION}

ESOP (employee stock ownership plan) is a kind of institutional arrangement which can make the employee become the stockholder of the enterprise and share the income of the enterprise and even participate in the corporate governance. This institutional arrangement makes the enterprise employees no longer limited to a single labor role, but both workers and capital owners to participate in the operation of the enterprise, share profits, share risks. Employee stock ownership originated in America in 1920s and flourished in 1970s. After more than 40 years' development, Employee stock ownership has become an important property right system abroad. Currently, about 28 million people in the United States are involved in various forms of employee stock ownership plans, involving assets totaling more than \$1 trillion. 1

In the mid-1980s, with the development of the corporate system of state-owned enterprises and the reform of the shareholding system, the ESOP (employee stock ownership plan) system was once vigorously implemented as an important institutional reform in various places, but due to the lack of top-level planning, System design defects and other reasons, the system in practice, and finally was called to stop several times, China's employee stock ownership attempts will not end. However, with the proposal of the third Plenary session of the 18th CPC Central Committee that "the mixed ownership economy be allowed to implement the ownership of employees in enterprises and form a community of capital owners and workers", it provides policy guidance opinions for the ESOP (employee stock ownership plan) system. In June 2014, China Securities Regulatory Commission (CSRC) formulated and issued the guidance opinions on the implementation of the ESOP (employee stock ownership plan) selected points in listed companies (hereinafter referred to as the guidance opinions), which marks that the ESOP (employee stock ownership plan) system has come to the front of the stage again. Under the government's high concern, the market has also responded positively to the ESOP arrangement. From June 2014 to the end of October 2015, 370 listed companies have announced the ESOP (employee stock ownership plan) plan, which shows the vitality of the ESOP (employee stock ownership plan) system.

However, why does the ESOP (employee stock ownership plan) get the favor of so many listed companies? The existing theories mainly analyze the motivation of implementing ESOP (employee stock ownership plan) from two aspects. On the one hand, it is the incentive theory that the implementation of ESOP (employee stock ownership plan) can effectively reduce agency cost, stimulate the work enthusiasm of employees and achieve the purpose of improving the performance of the company. On the other hand, as a system arrangement, ESOP (employee stock ownership plan) can effectively improve the decision-making mechanism and improve corporate governance by making employees with first-line production information participate in the planning and decision-making of the company. However, according to Lu Changjiang (2011), due to the imperfection of corporate governance structure in China, there is often a phenomenon that senior executives in our country actually seek for their own welfare in the name of equity incentive. And after we conducted a statistics on the proportion of senior executive stock ownership in the ESOP (employee stock ownership plan) of the listed companies in the ESOP (employee stock ownership plan) total shares, we found that the result was shown in "Table I". 
TABLE I. STATISTICS ON THE PROPORTION OF SENIOR EXECUTIVES IN THE EMPLOYEE STOCK OWNERSHIP PLAN OF LISTED COMPANIES IN CHINA

\begin{tabular}{lcccc}
\hline $\begin{array}{l}\text { Proportion of Senior } \\
\text { Executives In Shares }\end{array}$ & Quantity & Average & $\begin{array}{c}\text { Least } \\
\text { Value }\end{array}$ & $\begin{array}{c}\text { Maximum } \\
\text { Value }\end{array}$ \\
\hline$[50 \%, 100 \%]$ & 47 & 61.82 & 50 & 100 \\
{$[20 \%, 50 \%)$} & 145 & 32.02 & 20 & 49.74 \\
{$[0 \%, 20 \%)$} & 139 & 9 & 0 & 19.6 \\
\hline Total & 331 & 24.55 & 0 & 100 \\
\hline
\end{tabular}

As can be seen from "Table I", there are 47 companies with senior executives holding over $50 \%$ of all shares of the employee stock ownership plan, with an average share of senior executives holding up to $61.82 \%$, of which the highest or even $100 \%$ is the senior executive stock. The number of listed companies holding more than $20 \%$ senior executives is 145 , accounting for more than $40 \%$ of all employee Holding Company, and its average executive shareholding ratio has reached $32 \%$. As a result, the goal of implementing ESOs(employee stock ownership) in these listed companies is obviously more inclined to senior executives, and the ESOP (employee stock ownership plan) implementation requirements are significantly lower than equity incentives, will there be a situation in which listed companies use ESOP (employee stock ownership plan) to obtain benefits for their senior executives?

\section{LITERATURE REVIEW AND THEORETICAL HYPOTHESIS}

The existing literature mainly analyzes the motivation of employee stock ownership in listed companies from three aspects: encouraging employees, perfecting corporate governance and motivating senior executives' welfare.

\section{A. Motivate Employees}

In the wave of employee stock ownership implemented in the 1990s in our country, the phenomenon of the loss of stateowned assets that has been criticized for the implementation of employee stock ownership in state-owned enterprises has appeared. This will lead to more careful consideration of whether to implement ESOP in the new round of ESOP (employee stock ownership plan) implementation. On the other hand, compared with private enterprises, state-owned enterprises have more diversified responsibilities. Therefore, it is difficult to clearly define the contribution of employees' efforts to corporate performance in state-owned enterprises that do not aim at economic performance, and implement the goal that employee ownership is difficult to encourage (Huang Qunhui 2014). Finally, unlike state-owned executives who are more likely to target non-monetary earnings and future political careers, private senior executives are often more motivated to opt for employee stock ownership in order to motivate employees to work and improve performance. Therefore, the ownership of listed companies will have an important impact on the choice of employee ownership system. On this basis, we propose

Hypothesis 1.1: Compared with state-owned enterprises, private enterprises have more motivation to choose employee ownership.

Lu Changjiang (2011) believes that when listed companies are faced with a higher degree of market-oriented external environment, the company will operate more in accordance with market rules, so the higher the correlation between performance and employee effort. Due to the factors of policy, location, transportation and so on, the development of listed companies in the region is often unbalanced, and the external environment such as the degree of market competition and the level of rule of law are very different (He Yanlin and so on 2014). Fan Gang et al. (2011) pointed out in the report on the relative process of marketization in various regions of China that there are also obvious gaps in the development of nonstate-owned economy, the development of the product market, the development degree of the factor market and the development of market intermediary organizations in the East, middle and western regions of China..Therefore, we have reason to suppose that the degree of marketization will affect the choice of listed companies for ESOP (employee stock ownership plan).

\section{On this basis, we propose}

Hypothesis 1.2: Compared with the regions with low degree of marketization, companies with high degree of marketization are more motivated to choose employee stock ownership.

In high-tech enterprises with high knowledge content, the influence of human capital of employees on the competitiveness of enterprises is often higher than that of other industries (Rui Mingjie 2002). Therefore, in order to retain and attract talent, high-tech enterprises will have more incentive to implement employee stock ownership plan. In addition, Wang Hua (2006) argues that, compared with ordinary enterprises, high-tech enterprises usually have the characteristics of high growth and high growth value, which requires the business operators of enterprises to maintain long-term stability. This long-term stable demand will encourage business operators to implement long-term stable equity incentives.

On this basis, we propose

Hypothesis 1.3: Compared with non-high-tech enterprises, high-tech enterprises have more motivation to choose employee ownership.

\section{B. Perfecting the Motivation of Corporate Governance}

Huang Qunhui et al (2014) think that ESOP (employee stock ownership plan) is a kind of institutional arrangement with "incentive and governance double effect", which has the institutional effect of perfecting corporate governance relationship and economic organization form. Therefore, with the expansion of the scale of listed companies, it will be more difficult for shareholders to understand the company, followed by more prominent agency problems than small companies. Therefore, because of the difficulty of shareholders' supervision on managers in large scale companies, shareholders often have more motivation to use ESOP (employee stock ownership plan) as an internal supervision mechanism to alleviate the agency problem. On this basis, we propose hypothesis 2.1: larger companies are more motivated to choose employee shareholding than smaller firms.

In addition, when shareholders regard the ESOP (employee stock ownership plan) system as a governance mechanism to 
improve the internal supervision of the company, the ESOP (employee stock ownership plan) system will play a supervisory role which partly overlaps with that played by the independent directors and the supervisory board. Weisbach (1988) also pointed out that there is a negative relationship between the proportion of independent directors and equity incentive. He believes that independent directors' supervisory role and equity incentive are two ways to reduce agency costs, so there is a substitute relationship between them.

\section{On this basis, we propose}

Hypothesis 2.2: Compared with more independent directors, companies with less independent directors are more motivated to choose employee stock ownership.

Hypothesis 2.3: Compared with the larger number of board of supervisors, companies with less board of supervisors are more motivated to choose employee stock ownership.

Finally, according to Lu Changjiang (2011), because the ownership structure of listed companies in China is generally concentrated, shareholders often need to perfect the internal supervision system of the company in order to supervise the management In enterprises with relatively concentrated equity. Therefore, among the companies with high concentration of equity, shareholders are more motivated to use employee stock ownership as an internal supervision mechanism to solve the agency problem. On this basis, we propose hypothesis 2.4: companies with more concentrated shares have more incentive to choose employee shareholdings than those with more dispersed equity.

\section{Senior Executive Welfare}

According to Lv Changjiang (2011), due to the imperfection of corporate governance structure, Chinese executives often seek for their own welfare in the name of incentives. Compared with equity incentives, ESOs(employee stock ownership) can also be directed to the management of the company, but the difference is that when the company's financial statements for the most recent fiscal year are issued a negative opinion or are unable to express their opinions, or when the CSRC (China Securities Regulatory Commission) has imposed administrative penalties on the company for material irregularities in the last year, Listed companies will be banned from offering equity incentives, but there are no restrictions on employee ownership plans. In addition, ESO (employee stock ownership) also does not have a threshold for exercising power conditions such as what performance requirements are met, therefore, for the sake of self-interest, senior executives who have failed in equity incentives due to previous underperformance will be more motivated to choose employee ownership for their own profit, and in this case, the proportion of senior managers holding shares in the ESOP (employee stock ownership plan) will be higher. On this basis, we propose

Hypothesis 3: Compared with the successful implementation of equity incentive companies, the previous stock incentive failure companies have more incentive to choose employee stock ownership.

\section{Other Factors Affecting the Selection of Employee Stock Ownership System}

For the enterprises in the control industry, because the regulated industry is often the key industry related to the national economy and the people's livelihood, its enterprise goal is not simply the pursuit of economic performance, so the more government intervention, the smaller the measurement evaluation of the accounting performance (Liu Fengwei, 2007), the motivation of its employee stock ownership is also weaker. At the same time, in the guidance opinions, it also clearly stipulates that "the law prohibits the holding of employees in specific industry companies, buying and selling stocks, not being held in the name of ESOP (employee stock ownership plan), buying and selling stocks", and weakening the motivation of enterprises in the control industry to implement ESOP (employee stock ownership plan). On this basis, we propose

Hypothesis 4.1: Companies in non-regulated industries are more motivated to choose employee ownership than government-regulated industries.

Yemark (1995) argued that companies facing liquidity constraints would be more motivated to use equity compensation instead of cash payments to reduce cash payments. Therefore, illiquid companies will have a greater incentive to use equity to reduce cash compensation to ease the company's liquidity pressure. At this point, employee ownership system is used to ease the company liquidity restrictions. However, most of the ESOP funds in Chinese listed companies come from self-financing, which to some extent confirms this view. On this basis, we propose

Hypothesis 4.2: Companies with lower free cash flows are more motivated to choose employee ownership than those with higher free cash flows.

\section{EMPIRICAL STUDY}

\section{A. Sample Selection}

In this paper, we choose all listed companies in Shanghai and Shenzhen Stock Exchange in 2014 as the initial sample, we carry out the following screening procedures to the above samples: (1) remove St and St listed companies; (2) remove new third board listed companies; (3) listed companies that exclude incomplete data of required variables. After the above sieve sequence, we get the observation value of 2399 listed companies. Among them, 332 listed companies were listed as ESOP (employee stock ownership plan) before October 27, 2015 , accounting for $13.83 \%$ of the total listed companies. In terms of time distribution, there were 38 in 2014 and 294 in 2015 .

The data in this paper come from Wanda Database (win), Guo Tai'an Database (CSMAR) and Reese Database (RESSET). The division of high-tech enterprises in this paper refers to the division of $\mathrm{Li} \mathrm{Li}$ et al. (2014), selecting industries as pharmaceutical manufacturing, railway, communications, aerospace and other equipment manufacturing, software and information services, computers, Communications and other electronic equipment manufacturing, Internet and related 
services research and experimental development industry, instrumentation manufacturing enterprises as high-tech enterprises. With regard to the division of regulatory industries, this paper refers to the classification criteria of Xia Lijun (2007) and Lv Changjiang (2011), which will be classified as extractive industries; petroleum, chemistry, plastics, plastics; metals, non-metals; electricity, gas and water production and supply; transportation, Warehousing industry; information technology industry is divided into regulatory industries. For the classification of the failure of equity incentive, this paper chooses the criteria of whether the equity incentive scheme has been published since 2006 but has not been terminated or rejected. Excluding the delisting companies (1) and St (1), 62 successful companies (62) were given equity incentives again after failure, and 112 listed companies with failed equity incentives were finally obtained. For the marketization index, this paper refers to the marketization index in the "China Marketization Index-2011 report on the relative process of marketization in various regions". In addition, this paper uses actual controllers to divide the state-owned and private attributes of listed companies. The distribution of the sample is roughly as shown in "Table II":

TABLE II. ANALYSIS OF SAMPLE POPULATION DisTRIBUTION

\begin{tabular}{|c|c|c|c|c|}
\hline & Characteristic & $\begin{array}{c}\text { Implementation } \\
\text { Ratio }(\%)\end{array}$ & Difference & $\begin{array}{l}\text { Wilcoxon } \\
\text { Checkout }\end{array}$ \\
\hline \multirow{3}{*}{$\begin{array}{l}\text { Company } \\
\text { attributes }\end{array}$} & State-owned & 4.2 & \multirow[b]{2}{*}{-16.26} & \multirow{3}{*}{$-11.34 * * *$} \\
\hline & $\begin{array}{l}\text { Privately } \\
\text { operated }\end{array}$ & 20.46 & & \\
\hline & Low & 11.59 & \multirow[b]{2}{*}{-4.49} & \\
\hline Marketization & High & 16.08 & & $-3.18 * * *$ \\
\hline \multirow{2}{*}{$\begin{array}{l}\text { Equity incentive } \\
\text { failure }\end{array}$} & Not failed & 13.42 & \multirow{2}{*}{-8.9} & \multirow{2}{*}{$-2.66^{* * *}$} \\
\hline & failed & 22.32 & & \\
\hline \multirow{2}{*}{$\begin{array}{l}\text { High-tech } \\
\text { enterprises }\end{array}$} & High-tech & 18.95 & \multirow{2}{*}{6.5} & \multirow{2}{*}{$-3.77 * * *$} \\
\hline & Non-high-tech & 12.45 & & \\
\hline \multirow[t]{2}{*}{ Regulatory } & Regulatory & 11.76 & \multirow[t]{2}{*}{-3.08} & \multirow[t]{2}{*}{$2.05^{*}$} \\
\hline & Non-regulatory & 14.84 & & \\
\hline
\end{tabular}

a. Note : *,**,*** respectively $10 \%, 5 \%, 1 \%$ below significant, similarly hereinafter.

As shown in "Table I", the proportion of private enterprises implementing significant employee shareholding scheme is much higher than that of state-owned enterprises from the attribute of the company, from which we can see that private enterprises have more motivation to choose employee stock ownership. From the point of view of marketization, areas with high degree of marketization tend to implement ESO (employee stock ownership). From the point of view of failure of equity incentive, $22.32 \%$ of the companies that have experienced the failure of equity incentive choose to implement employee stock ownership. In addition, the tendency of hi-tech enterprises to choose employee shareholding is significantly higher than that of non-high-tech enterprises, and the motivation of employee stock ownership is obviously lower than that of non-regulated companies in the industries regulated by the government.

\section{B. Model Specification}

In this paper, A share listed companies in Shanghai and Shenzhen stock markets are divided into two groups according to whether or not to implement ESO(employee stock ownership), and then analyzed the differences between the two types of companies by descriptive statistics, and then used LOGISTIC regression to carry out multi-factor test. The regression model is shown below. Table III shows the relevant variables :

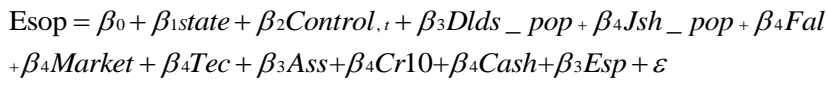

This paper first carries on the regression to the whole sample, but because the research variable is many, the design company characteristic and the corporate governance two levels, to avoid the effect of multi-collinearity on the regression results in company data. According to the method of Lv Changjiang (2011), based on the whole sample regression, regression of each factor of company characteristics and variables of corporate governance level is made. In addition, in order to avoid the influence of industry factors and extreme values on the regression results, the characteristic data of company in this paper have been adjusted by the industry average, standardized treatment and tailshrinking treatment at the level of $1 \%$ and $99 \%$. 
TABLE III. VARIABLE DECLARATION

\begin{tabular}{|c|c|c|c|c|}
\hline & Variable Name & Definition & Introduction & Expected Symbol \\
\hline Dependent variable & Esop & $\begin{array}{l}\text { Dependent variable. Whether to choose ESOP, Yes } \\
1 \text {, No } 0\end{array}$ & & \\
\hline \multirow{4}{*}{ Motivate employees } & state & Whether it is a private enterprise or not. Yes 1 , No 0 & & + \\
\hline & marcket & Marketization index & & + \\
\hline & tec & $\begin{array}{l}\text { Whether it is a high-tech company or noy, Yes } 1 \text {, } \\
\text { No } 0\end{array}$ & & + \\
\hline & esp & Company growth & $\begin{array}{l}\text { Basic earnings per share } \\
\text { (Year-on-year growth rate) }\end{array}$ & + \\
\hline $\begin{array}{l}\text { Senior executive } \\
\text { welfare }\end{array}$ & fal & Has the equity incentive failed,Yes 1 , No 0 & & + \\
\hline \multirow{4}{*}{$\begin{array}{l}\text { erfect corporate } \\
\text { governance }\end{array}$} & control & $\begin{array}{l}\text { Whether it is a government regulated industry, Yes } \\
1 \text {, No } 0\end{array}$ & & - \\
\hline & dlds_pop & Number of independent directors & & - \\
\hline & jsh_pop & Number of supervisory boards & & - \\
\hline & $\operatorname{cr} 10$ & Equity concentration & $\begin{array}{l}\text { The sum of the top } 10 \\
\text { shareholders }\end{array}$ & - \\
\hline \multirow[t]{2}{*}{ Other } & cash & Free cash flow & $\begin{array}{l}{[(\text { net margin }+ \text { interest cost }+} \\
\text { non-cash charges })- \text { Working } \\
\text { capital supplementary-capital } \\
\text { expenditure }) / \text { Total assets }\end{array}$ & + \\
\hline & asset & Natural logarithm of assets & & + \\
\hline
\end{tabular}

\section{EMPIRICAL RESULTS}

\section{A. Statistical Description}

Table IV is a descriptive statistical analysis of the variables of the two types of samples after the implementation of the ESOP (employee stock ownership plan). As shown in "Table IV", from the corporate feature level, $87.7 \%$ of the listed companies that choose to carry out the ESOP plan are private enterprises. Again, this paper assumes that this article assumes 1-1. The motivation of implementing ESOP (employee stock ownership plan) of listed companies in regulated industries is weaker than that of non-regulated industries, from the perspective of marketization, the marketization index of ESOP (employee stock ownership plan) companies is significantly higher than that of those who do not choose ESOP (employee stock ownership plan). From the point of view of the failure of equity incentive, the proportion of listed companies that have experienced the failure of equity incentive is significantly higher than that of listed companies without employee holding. It shows that companies with failed equity incentive have stronger motivation to implement (employee stock ownership plan). And from the point of view of the company's technical content, high and new technology accounts for nearly $30 \%$ of the companies that choose employee shareholding, which is obviously more motivated to implement employee stock ownership plan.
For variables on the corporate governance level, the average size of the listed company with employee shareholding is much smaller than that of the company without employee ownership, but the degree of equity concentration is higher than that of the listed company without employee ownership, indicating that the scale is small. Listed companies with higher concentration tend to have more incentive to implement ESOP (employee stock ownership plan). Moreover, companies with a small number of independent directors and supervisory boards tend to opt for employee stock ownership. However, we have not found the influence of free cash flow on the choice of employee shareholding, and the growth index of the company with employee ownership is higher than that of the company without employee ownership, regardless of the average value or median. It shows that companies with high growth are more motivated to choose employee shareholding. 
TABLE IV. VARIABLE DESCRIPTIVE STATISTICS

\begin{tabular}{|c|c|c|c|c|c|c|c|c|}
\hline & \multicolumn{3}{|c|}{$\begin{array}{c}\text { Companies That Choose ESOP } \\
\text { (Employee Stock Ownership Plan) }\end{array}$} & \multicolumn{3}{|c|}{$\begin{array}{c}\text { Companies That Don't Choose } \\
\text { ESOP (Employee Stock Ownership } \\
\text { Plan) }\end{array}$} & \multirow{2}{*}{$\begin{array}{l}\text { Mean Value } \\
\text { Checkout }\end{array}$} & \multirow{2}{*}{$\begin{array}{c}\text { Mann-Whitney } \\
\text { U checkout }\end{array}$} \\
\hline & Average & Median & $\begin{array}{l}\text { Standard } \\
\text { deviation }\end{array}$ & Average & Median & $\begin{array}{l}\text { Standard } \\
\text { deviation }\end{array}$ & & \\
\hline Private enterprise & 0.877 & 1 & 0.329 & 0.547 & 1 & 0.498 & $-11.65^{* * * *}$ & $-11.33 * * *$ \\
\hline Regulatory industry & 0.277 & 0 & 0.448 & 0.334 & 0 & 0.472 & $2.04 * *$ & $2.046 * *$ \\
\hline Marketization index & 9.573 & 9.87 & 1.889 & 9.185 & 9.87 & 2.045 & $-3.19 * * *$ & $-3.18 * * *$ \\
\hline $\begin{array}{l}\text { Equity incentive } \\
\text { Fail }\end{array}$ & 0.075 & 0 & 0.264 & 0.042 & 0 & 0.201 & $-2.67 * * *$ & $-2.66 * * *$ \\
\hline High-tech enterprises & 0.292 & 0 & 0.455 & 0.201 & 0 & 0.401 & $-3.78^{* * *}$ & $-3.77 * * *$ \\
\hline Number of independent directors & 3.964 & 3 & 1.424 & 4.56 & 4 & 1.711 & $6.02 * * *$ & $6.45^{* * *}$ \\
\hline Number of supervisory boards & 4.145 & 3 & 1.887 & 4.986 & 4 & 2.404 & $6.09 * * *$ & $6.71^{* * *}$ \\
\hline Scale & 0.023 & -0.101 & 1.029 & 0.157 & 0.024 & 1.315 & $1.78^{*}$ & 1.64 \\
\hline Equity concentration & 0.06 & 0.096 & 0.812 & -0.04 & -0.01 & 0.98 & $-1.76^{*}$ & $-1.72 *$ \\
\hline Free cash flow & -0.012 & -0.001 & 0.092 & -0.013 & 0 & 0.107 & -0.21 & 0.06 \\
\hline Growth & -0.006 & 0.003 & 0.094 & -0.022 & 0 & 0.154 & $-1.83^{*}$ & $-1.94 *$ \\
\hline
\end{tabular}

\section{B. Regression Results}

In the regression test, this paper first carries on the regression to all the variables, considering the incentive demand variable and the executive welfare variable correlation variable often has the obvious correlation, This paper chooses to regress each factor of incentive demand variables and senior executive welfare with variables at the corporate governance level, the results are shown as shown in "Table V":

TABLE V. REGRESSION RESULTS

\begin{tabular}{|c|c|c|c|c|c|c|c|}
\hline & (1) & (2) & (3) & (4) & (5) & (6) & (7) \\
\hline Private enterprise & $\begin{array}{l}1.697 * * * \\
(8.91)\end{array}$ & $\begin{array}{l}1.740 * * * \\
(9.23)\end{array}$ & & & & & \\
\hline Marketization index & $\begin{array}{l}0.006 \\
(0.20)\end{array}$ & & $\begin{array}{l}0.057 * \\
(1.82)\end{array}$ & & & & \\
\hline High-tech enterprises & $\begin{array}{l}0.279 * * \\
(2.00)\end{array}$ & & & $\begin{array}{l}0.395 * * * \\
(2.90)\end{array}$ & & & \\
\hline Growth & $\begin{array}{l}0.411 \\
(0.77)\end{array}$ & & & & $\begin{array}{l}0.746 \\
(1.41)\end{array}$ & & \\
\hline Equity incentive failure & $\begin{array}{l}0.335 \\
(1.37)\end{array}$ & & & & & $\begin{array}{l}0.547 * * \\
(2.28)\end{array}$ & \\
\hline Free cash flow & $\begin{array}{l}0.258 \\
(0.45)\end{array}$ & & & & & & $\begin{array}{l}0.182 \\
(0.32)\end{array}$ \\
\hline Regulatory industry & $\begin{array}{l}-0.098 \\
(-0.72)\end{array}$ & $\begin{array}{l}-0.111 \\
(-0.82)\end{array}$ & $\begin{array}{l}-0.179 \\
(-1.34)\end{array}$ & $\begin{array}{l}-0.188 \\
(-1.41)\end{array}$ & $\begin{array}{l}-0.186 \\
(-1.40)\end{array}$ & $\begin{array}{l}-0.194 \\
(-1.45)\end{array}$ & $\begin{array}{l}-0.199 \\
(-1.49)\end{array}$ \\
\hline Scale & $\begin{array}{l}0.153 * * * \\
(2.69)\end{array}$ & $\begin{array}{l}0.147 * * * \\
(2.62)\end{array}$ & $\begin{array}{l}-0.018 \\
(-0.35)\end{array}$ & $\begin{array}{l}-0.002 \\
(-0.04)\end{array}$ & $\begin{array}{l}-0.018 \\
(-0.35)\end{array}$ & $\begin{array}{l}-0.020 \\
(-0.39)\end{array}$ & $\begin{array}{l}-0.019 \\
(-0.36)\end{array}$ \\
\hline $\begin{array}{l}\text { Number of independent directors } \\
\text { Number of supervisory boards }\end{array}$ & $\begin{array}{l}-0.174 * * * \\
(-3.78)\end{array}$ & $\begin{array}{l}-0.176^{* * *} \\
(-3.83)\end{array}$ & $\begin{array}{l}-0.182 * * * \\
(-3.99)\end{array}$ & $\begin{array}{l}-0.183 * * * \\
(-4.03)\end{array}$ & $\begin{array}{l}-0.184 * * * \\
(-4.04)\end{array}$ & $\begin{array}{l}-0.182 * * * \\
(-4.00)\end{array}$ & $\begin{array}{l}-0.183 * * * \\
(-4.03)\end{array}$ \\
\hline Number of independent directors & $\begin{array}{l}-0.033 \\
(-0.89)\end{array}$ & $\begin{array}{l}-0.037 \\
(-1.02)\end{array}$ & $\begin{array}{l}-0.138 * * * \\
(-3.89)\end{array}$ & $\begin{array}{l}-0.140^{* * * *} \\
(-3.95)\end{array}$ & $\begin{array}{l}-0.144 * * * \\
(-4.09)\end{array}$ & $\begin{array}{l}-0.144 * * * \\
(-4.07)\end{array}$ & $\begin{array}{l}-0.146 * * * \\
(-4.16)\end{array}$ \\
\hline Equity concentration & $\begin{array}{l}0.071 \\
(1.06)\end{array}$ & $\begin{array}{l}0.064 \\
(0.98)\end{array}$ & $\begin{array}{l}0.084 \\
(1.29)\end{array}$ & $\begin{array}{l}0.099 \\
(1.52)\end{array}$ & $\begin{array}{l}0.090 \\
(1.39)\end{array}$ & $\begin{array}{l}0.101 \\
(1.56)\end{array}$ & $\begin{array}{l}0.095 \\
(1.46)\end{array}$ \\
\hline Nodal increment & $\begin{array}{l}-2.315^{* * *} \\
(-5.38)\end{array}$ & $\begin{array}{l}-2.172 * * * \\
(-7.45)\end{array}$ & $\begin{array}{l}-0.920 * * \\
(-2.36)\end{array}$ & $\begin{array}{l}-0.464 * * \\
(-2.12)\end{array}$ & $\begin{array}{l}-0.332 \\
(-1.56)\end{array}$ & $\begin{array}{l}-0.381 * \\
(-1.78)\end{array}$ & $\begin{array}{l}-0.327 \\
(-1.54)\end{array}$ \\
\hline Sample & 2399 & 2399 & 2399 & 2399 & 2399 & 2399 & 2399 \\
\hline r2_p & 0.095 & 0.092 & 0.036 & 0.039 & 0.036 & 0.037 & 0.035 \\
\hline
\end{tabular}

The regression equation (1) is the result of regression of all the factors that influence the listed company to choose and implement the ESOP (employee stock ownership plan). Equations (2) to (7) are the results of regression between incentive demand motivation factors and executive welfare factors and corporate governance demand factors. From the above results, from the aspect of incentive demand, whether in equation (1) or (2), the coefficients of private enterprises are significantly positive at the level of $1 \%$, which is consistent with the expectation, and supports the hypothesis of 1.1 , which 
shows that private enterprises have more motivation to implement employee stock ownership. For the market-oriented index, the coefficients are positive in equation (1) and (3), although they are not significant in equation (1), they are significant at the level of $10 \%$ after the co-linearity is excluded. Supposing 1.2 indicates that enterprises in the higher degree of marketization are more motivated to implement ESOP (employee stock ownership plan). For high-tech enterprises, the coefficients in equation (1) are positive at the significant level of 5\%, and when the influence of collinearity is excluded, the coefficients are significantly positive at the level of $1 \%$. Supporting hypothesis 1.3 indicates that high-tech enterprises are more motivated to implement ESOP (employee stock ownership plan).

From the aspect of corporate governance demand, the coefficients of corporate size are significantly positive in equations (1) and (2), although they are negative in equations (3) to (5), they are not significant. Support hypothesis 2.1, indicating that larger companies are more motivated to implement ESOP (employee stock ownership plan). In addition, the number of independent directors and the number of board of supervisors are both significantly negative, and the significant level is basically in 1 , which indicates that the companies with less number of independent directors and board of supervisors are more motivated to implement ESOP (employee stock ownership plan), which supports the hypothesis of 2.2 and 2.3. The coefficients of ownership concentration are all positive, which indicates that companies with more concentrated equity liquidity have more motivation to implement ESOP (employee stock ownership plan), but the results are not significant and cannot effectively support the hypothesis of 2.4 .

From the perspective of executive welfare demand, the coefficients are positive in equation (1) and (6) for those companies that have failed equity incentive, although they are not significant in equation (1). The coefficient is significantly positive at the level of $5 \%$, excluding the influence of collinearity. Support for hypothesis 3 shows that companies that have recently experienced equity failures are more motivated to implement ESOs (employee stock ownership). The coefficient of regulation industry is all negative, same as expected, but it is not significant in equations (1) to (7), assuming 4.1 cannot be supported.

\section{CONCLUSION}

This paper studies the motivation of selecting employee stock ownership plan from three aspects of incentive motivation, corporate governance motivation and high - tube welfare motivation. The results of the study show that, motivating employees to work actively and improving corporate governance are the main motivations for listed companies to implement employee stock ownership plans. In particular, private enterprises, high - tech enterprises, large scale enterprises as well as enterprises with a small number of independent directors and board of supervisors are more inclined to implement employee holding. In addition, listed companies that have experienced earlier equity incentives are more motivated to implement employee holding.

\section{REFERENCES}

[1] Fang Zhulan. It is a trend for owners of human capital to own enterprise ownership. [J]. economic research,1997(6).

[2] Tang Xinlin. Summary of the International Symposium on the Construction of ESOP system in Chinese Enterprises [J]. Economic dynamics, 2001(4).

[3] Huang Qunhui, Yu Jing,Wang Xin, Shao Jingting. Research on Chinese employee Stock ownership system in the New era [J]. China's industrial economy, 2014(7).

[4] Zhang Xian, Hu Mao. The Development Dilemma and realistic Choice of ESOP in Chinese Enterprises [J]. Social science research, 2015(1).

[5] Lv Changjiang. Why listed companies choose equity incentive [J]. accounting study,2011(1).

[6] Wang Wenbing, Gan Shengdao, Duan Huayou. ESOP: an expected trial-and comment on "the interim measures for the Management of ESOP in listed companies (draft for soliciting opinions)"; [J]. Discussion on Modern economy,2012(11).

[7] Zhao Lixin. Employee Stock ownership is an effective way to construct Modern Enterprise system [J]. Economic dynamics,2000(4).

[8] Li Li,Yan Bin,Gu Chunxia. Intellectual property Protection, Information asymmetry and High-tech Enterprise Capital [J]. Manage the world,2014(11).

[9] Xia Lijun, Chen Xinyuan. The process of marketization, the Reform Strategy of State-owned Enterprises and the Endogenous decision of Corporate Governance structure [J]. Economic research,2007(11).

[10] Fan Gang, Wang Xiaolu, Zhu Hengpeng. A report on the relative process of marketization in various regions in China- - 2011 report on the relative process of marketization in various regions [M]. Economic science publishing house, 2011. 